\title{
Effect of recombinant porcine IGF-binding protein-3 on proliferation of embryonic porcine myogenic cell cultures in the presence and absence of IGF-I
}

\author{
M S Pampusch, E Kamanga-Sollo, M E White, M R Hathaway \\ and W R Dayton
}

Animal Growth and Development Laboratory, Department of Animal Science, University of Minnesota, 348 ABLMS, 1354 Eckles Avenue, St Paul, Minnesota 55108, USA

(Requests for offprints should be addressed to W R Dayton; Email: wdayton@umn.edu)

\begin{abstract}
IGF-binding protein (IGFBP)-3 is produced by cultured porcine embryonic myogenic cell (PEMC) cultures and is secreted into the medium. Levels of secreted IGFBP-3 and IGFBP-3 mRNA are significantly reduced during differentiation and increase after differentiation is complete, suggesting that IGFBP-3 may play some role in myogenesis and/or in changes in myogenic cell proliferation that accompany differentiation. IGFBP-3 reportedly may either suppress or stimulate proliferation of cultured cells depending on cell type. Additionally, IGFBP-3 has been shown to affect proliferation via both IGF-dependent and IGF-independent mechanisms in some cell types but not all. Currently, the effect, if any, of IGFBP-3 on myogenic cell proliferation is not known. Consequently, the goal of this study was to assess the IGF-I-dependent and IGF-Iindependent actions of recombinant porcine IGFBP-3 on proliferation of cultured porcine myogenic cells. To facilitate these investigations, we have expressed porcine
\end{abstract}

IGFBP-3 in the baculovirus system, purified and characterized the expressed recombinant porcine IGFBP-3 (rpIGFBP-3), and produced and characterized an antiporcine IGFBP-3 antibody that neutralizes the biological activity of porcine IGFBP-3. rpIGFBP-3 suppressed IGF-I-stimulated proliferation of PEMCs in a concentration-dependent manner with equimolar concentrations of IGF-I and rpIGFBP-3, resulting in complete suppression of IGF-I-stimulated proliferation. rpIGFBP-3 also suppressed Long-R3-IGF-I-stimulated proliferation of PEMC, indicating that rpIGFBP-3 possesses IGFindependent activity in this cell system. These data have established that IGFBP-3 has the potential to affect proliferation of PEMCs during critical periods of muscle development that may impact ultimate muscle mass achievable postnatally.

Journal of Endocrinology (2003) 176, 227-235

\section{Introduction}

Insulin-like growth factors (IGF)-I and -II have significant effects on both differentiation and proliferation of myogenic cells (Florini et al. 1996, Lawlor \& Rotwein 2000, Tureckova et al. 2001). The actions of IGFs are regulated by members of the IGF-binding protein (IGFBP) family consisting of six proteins that bind IGF-I and -II with high affinity (Clemmons 1998, Hwa et al. 1999, Baxter 2000). Binding of IGF to IGFBPs has been shown to increase the stability of the IGFs and to affect their biological activity (Clemmons 1998, Hwa et al. 1999, Baxter 2000). Additionally, IGFBP-1, -3 and -5 reportedly exert IGFindependent actions, possibly by binding to cell surface receptors (Clemmons 1998, Hwa et al. 1999, Baxter 2000).

IGFBP-3 is produced by a number of different cell types including porcine embryonic myogenic cells (PEMCs) and porcine muscle satellite cells (Hembree et al. 1996, Johnson et al. 1999, Dahlfors \& Arnqvist 2000, Granata et al. 2000, Jennische \& Hall 2000, Wabitsch et al. 2000, Drivdahl et al. 2001, Kveiborg et al. 2001, Yi et al. 2001). Although IGFBP-3 has generally been shown to suppress proliferation of cultured cells, it may also stimulate proliferation depending upon the cell type and the assay conditions (Baxter 2000, Baxter et al. 2000). IGFBP-3 binds to both IGF-I and -II with a high affinity thus making IGFs unavailable to bind to the type I IGF receptor that is responsible for many of their biological effects. IGFBP-3 also suppresses proliferation of cells that lack the type I IGF receptor suggesting that IGFBP-3 has effects on cell proliferation that are independent of IGF (Valentinis et al. 1995). Numerous studies using IGF analogs that bind to the type I IGF receptor but only weakly to IGFBP-3 have supported this initial hypothesis. Further support for the IGF-independent actions of 
IGFBP-3 is provided by the recent reports that IGFBP-3 stimulates phosphorylation of Smad proteins via the transforming growth factor- $\beta$ (TGF $\beta$ ) receptor pathway in T47D breast cancer cells (Fanayan et al. 2000, 2002). IGFBP-3 also reportedly binds to the type V TGF $\beta$ receptor and to several other less well-characterized cell surface proteins (Leal et al. 1999).

Cultured PEMCs produce IGFBP-3, and levels of IGFBP-3 mRNA and protein decrease significantly during differentiation and then increase after differentiation is complete (Hembree et al. 1996, Johnson et al. 1999, Yang et al. 1999). These changes in IGFBP-3 mRNA concentration during differentiation suggest that IGFBP-3 may play a role in myogenesis and/or alterations in proliferation of cultured PEMCs during differentiation. The goal of this study was to assess the IGF-I-dependent and IGF-Iindependent actions of recombinant porcine IGFBP-3 (rpIGFBP-3) on proliferation of cultured porcine myogenic cells. In order to facilitate these investigations, we have sequenced the full open reading frame of porcine IGFBP-3 cDNA, expressed this protein in the baculovirus system, purified and characterized the expressed rpIGFBP-3, and produced and characterized an antiporcine IGFBP-3 antibody that neutralizes the biological activity of porcine IGFBP-3.

\section{Materials and Methods}

\section{cDNA production}

The nucleotide sequence of porcine IGFBP-3 (including more than 100 nt of $5^{\prime}$-UTR sequence that was previously unreported) was obtained by using $5^{\prime}$-RACE PCR using porcine liver RNA (Accession no. AF085482). cDNA containing the full open reading frame of IGFBP-3 was amplified from porcine liver total RNA and cloned into a pT-Adv vector (Clontech, Palo Alto, CA, USA). IGFBP-3 was sequenced in both directions by fluorescent automated DNA sequencing (ABI Prizm Model 377; Applied Biosystems, Foster City, CA, USA). In order to reduce secondary structure, GC melt (Clontech) was included in the amplification mixture and 10\% DMSO was included in the sequencing mixture.

\section{Protein production}

Recombinant IGFBP-3 was produced in a baculovirus expression system by ATG Laboratories Inc. (Eden Prairie, MN, USA). IGFBP-3 cDNA was PCR cloned into the pGEM-T Easy plasmid and then subcloned into the baculovirus transfer vector (pBacHIS3) containing the sequence necessary to add six histidines to the $\mathrm{N}$-terminus (IGFBP-3-6 $\times$ HIS). Finally, IGFBP-3-6 $\times$ HIS was subcloned into a baculovirus expression vector (pACGP67B) containing a secretion signal. This construct produced
rpIGFBP-3 with an N-terminal baculovirus secretion signal and a six-histidine tag on the $\mathrm{N}$-terminus. The recombinant protein was produced in Trichoplusia ni (T. ni) 5B1-4 cells (High Five Cells, Invitrofen, Carlsbad, CA, USA) cells grown in serum-free conditions. Conditioned media were collected $48 \mathrm{~h}$ post-infection and stored at $-80{ }^{\circ} \mathrm{C}$.

\section{Protein purification}

Nickel-NTA affinity chromatography resin (Qiagen, Avalencia, CA, USA) was equilibrated in $10 \mathrm{mM}$

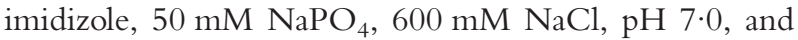
utilized to bind His-tagged rpIGFBP-3 as described in the Results section. An IGF-I affinity column was made by coupling $2 \mathrm{mg}$ recombinant IGF-I (GroPep, Adelaide, SA, Australia) to Affi-Gel 10 (BioRad Laboratories, Hercules, CA, USA) in $50 \mathrm{mM}$ HEPES, pH 6.5. The column was

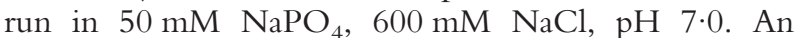
affinity column containing bound soluble proteins from uninfected $T$. ni cells was produced by coupling soluble proteins to a CnBr-activated Sepharose 4B column which was run in phosphate-buffered saline $(137 \mathrm{mM} \mathrm{NaCl}$, $2.7 \mathrm{mM} \quad \mathrm{KCl}, 10 \mathrm{mM}$ Na $2 \mathrm{HPO}_{4} \cdot 7 \mathrm{H}_{2} \mathrm{O}, 1.8 \mathrm{mM}$ $\left.\mathrm{KH}_{2} \mathrm{PO}_{4}\right)$.

\section{Antibody production}

Polyclonal antibodies to affinity-purified IGFBP-3 were produced in rabbits by Covance Research Products (Denver, PA, USA) using their standard protocols. The IgG was purified from serum by protein A chromatography.

\section{Electrophoresis}

Samples were run on 10\% polyacrylamide SDS gels according to the method of Laemmli (1970). Gels were stained with either GelCode Blue Stain (Pierce Chemical Company, Rockford, IL, USA) or with the GelCode Color Silver Stain Kit (Pierce Chemical Company).

\section{Western blotting}

Proteins were electrophoresed on a $10 \%$ polyacrylamide SDS gel and then transferred from the gel to a nitrocellulose membrane in $15 \mathrm{mM}$ glycine, 5\% methanol for $1 \mathrm{~h}$ at $100 \mathrm{~V}$. After the membrane was rinsed in Tris-buffered saline (TBS) $(10 \mathrm{mM}$ Tris- $\mathrm{HCl}, 150 \mathrm{mM}$ $\mathrm{NaCl}, \mathrm{pH} 7 \cdot 4$ ), it was blocked for $1.5 \mathrm{~h}$ in TBS containing $3 \%$ bovine serum albumin (BSA). The membrane was incubated in blocking buffer containing anti-rpIGFBP-3 (1:5000) for $1 \mathrm{~h}$ followed by several washes in TBS containing $0 \cdot 1 \%$ Tween 20 . The membrane was then incubated for $1 \mathrm{~h}$ with phosphatase-labeled goat anti-rabbit IgG (H+L) (KPL, Gaithersburg, MD, USA) 
(1:2500) in blocking buffer and washed several times with TBS containing $0 \cdot 1 \%$ Tween 20. Bands were detected using Lumi-Phos (Pierce Chemical Company).

\section{Ligand blotting}

Proteins were run on non-reducing SDS-PAGE and then transferred from the gel to a nitrocellulose membrane. Binding proteins were detected with ${ }^{125}$ I-IGF-I as described previously (Hembree et al. 1996, Yang et al. 1999).

\section{Isolation and culture of PEMCS}

PEMCs for culture were isolated from 50- to 55-day-old porcine fetuses and stored in liquid nitrogen as described in detail previously (Pampusch et al. 1990, Hembree et al. 1991, 1996). To establish cultures from frozen stocks, rapidly thawed cell suspensions were diluted with the appropriate amount of Dulbecco's modified Eagle's medium (DMEM) containing 7\% (v/v) swine serum (SS) (Hembree et al. 1991) and 3\% (v/v) chicken embryo extract (CEE) (Hembree et al. 1991) and plated in dishes coated with reduced growth factor basement membrane matrigel (BD, Bedford, MA, USA) diluted 1:100 (v/v) in DMEM. All cultures were maintained at $37{ }^{\circ} \mathrm{C}, 5 \% \mathrm{CO}_{2}$, $95 \%$ air in a water-saturated environment. After a 24-h attachment period, cultures were fed with $10 \mathrm{ml}$ DMEM containing $7 \% \mathrm{SS}$ and 3\% CEE.

\section{${ }^{3}$ H-Thymidine incorporation}

${ }^{3} \mathrm{H}$-Thymidine incorporation was measured as previously described (Yang et al. 1999). PEMC cultures were established in $2 \mathrm{~cm}^{2}$ wells as described previously. After $48 \mathrm{~h}$ in culture, serum-containing medium was removed and replaced with a serum-free medium (DMEM containing $250 \mu \mathrm{g}$ IGFBP-3-free fetuin and $100 \mu \mathrm{g}$ BSA-linoleic $\mathrm{acid} / \mathrm{ml}$ medium) containing IGF-I, Long-R3-IGF-I, rpIGFBP-3, and/or anti-rpIGFBP-3 antibody as indicated in specific Figure legends. IGFBP-3-free fetuin was prepared according to procedures described previously (Yang et al. 1999). After $6 \mathrm{~h}$, this washout medium was removed and $1 \mathrm{ml}$ fresh, serum-free medium identical to the media used in the washout was added to each culture. At $72 \mathrm{~h}$ in culture, ${ }^{3} \mathrm{H}$-thymidine was added to culture media $(1 \mu \mathrm{Ci} / \mathrm{ml}$ final concentration) and allowed to incubate at $37^{\circ} \mathrm{C}$ for $3 \mathrm{~h}$. Cells were rinsed with cold serum-free DMEM, and fixed with $1 \mathrm{ml}$ cold 5\% trichloroacetic acid (TCA) overnight at $4{ }^{\circ} \mathrm{C}$. Unincorporated ${ }^{3} \mathrm{H}$-thymidine was removed by aspirating the cold 5\% TCA and rinsing wells with additional cold 5\% TCA. ${ }^{3} \mathrm{H}$-Thymidine incorporation into cellular DNA was measured by dissolving cell material in $0.5 \mathrm{M} \mathrm{NaOH}$ and counting it in a scintillation counter. All data points are the average of values obtained from triplicate cultures.

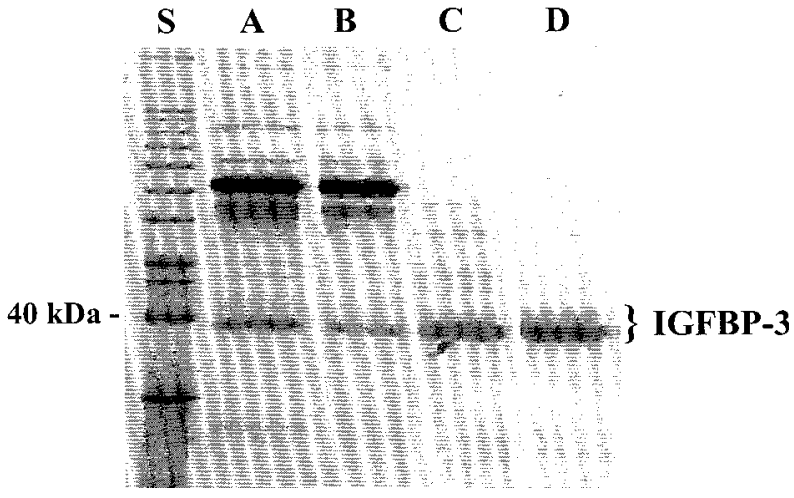

Figure 1 Silver-stained, 10\% polyacrylamide SDS gel of T. ni cell medium and rpIGFBP-3-containing fractions obtained at various steps in the purification of rpIGFBP-3. A: T. ni cell medium; B: dialyzed medum; C: rplGFBP-3 fraction eluting from the nickel-NTA affinity column; D: rpIGFBP-3 fraction eluting from the IGF-I affinity column; S: molecular weight standards.

\section{Results}

\section{Expression and purification of rpIGFBP-3}

Medium conditioned for $48 \mathrm{~h}$ by T. ni cells infected with baculovirus containing the rpIGFBP-3 construct contained rpIGFBP-3 that could be detected using ${ }^{125}$ I-IGF-I ligand blotting. This medium was dialyzed for $24 \mathrm{~h}$ against $10 \mathrm{mM}$ imidizole, $50 \mathrm{mM} \mathrm{NaPO}, 600 \mathrm{mM} \mathrm{NaCl}$, $\mathrm{pH} 7 \cdot 0$, and then for an additional $24 \mathrm{~h}$ against the same buffer at $\mathrm{pH} 8 \cdot 0$. The dialyzed, conditioned medium was mixed with nickel-NTA affinity chromatography resin for $1.5 \mathrm{~h}$ and then poured into a column. The column was washed with three column volumes of $15 \mathrm{mM}$ imidizole, $50 \mathrm{mM} \mathrm{NaPO}, 600 \mathrm{mM} \mathrm{NaCl}, \mathrm{pH} 8 \cdot 0$, and the rpIGFBP-3 was then eluted with $50 \mathrm{mM}$ imidizole, $50 \mathrm{mM} \mathrm{NaPO}$, $600 \mathrm{mM} \mathrm{NaCl}, \mathrm{pH} 8 \cdot 0$. A silver-stained SDS polyacrylamide gel showed that, although rpIGFPB-3 was greatly enriched in the column eluate as compared with the culture media, significant contaminants remained (Fig. 1). In order to further purify the nickel column eluate, its $\mathrm{pH}$ was lowered to $7 \cdot 4$ by addition of $1 \mathrm{M} \mathrm{HCl}$ and it was loaded onto an IGF-I affinity column. The column was washed with five column volumes of column

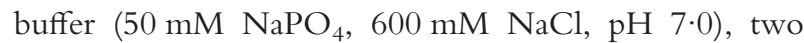
column volumes of column buffer without $\mathrm{NaCl}$, and $0 \cdot 5$ column volumes of $1 \cdot 0 \%(\mathrm{v} / \mathrm{v})$ acetic acid prior to elution of IGFBP-3 with 3 column volumes of $1 \cdot 0 \%(\mathrm{v} / \mathrm{v})$ acetic acid. Silver-stained SDS polyacrylamide gels showed that the rpIGFBP-3 fraction eluted from the IGF-I affinity column in $1.0 \%(\mathrm{v} / \mathrm{v})$ acetic acid contained proteins migrating at 41 and $39 \mathrm{kDa}$ (Fig. 1). These proteins were identified as IGFBP-3 based on the ability of both the 41 and $39 \mathrm{kDa}$ bands to bind ${ }^{125}$ I-IGF-I in the ligand blot assay (Fig. 2). Scanning densitometry showed that more 


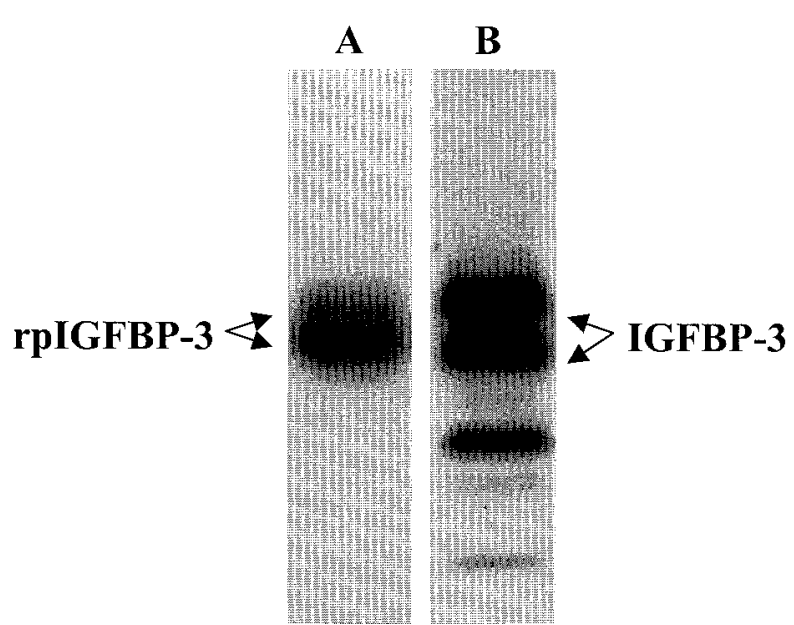

Figure $2{ }^{125}$ I-IGF-I Western ligand blot of purified rpIGFBP-3 and of porcine serum. Serum IGFBP-3 (B) bands at apparent molecular weights of 39 and $43 \mathrm{kDa}$. rplGFBP-3 (A) bands at apparent molecular weights of 39 and $41 \mathrm{kDa}$.

than $98 \%$ of the protein in this fraction was contained in the two rpIGFBP-3 bands. Two minor contaminating proteins banding at approximately $14 \mathrm{kDa}$ were also present in the purified rpIGFBP-3 fraction. Results obtained during production and characterization of antirpIGFBP-3 showed that these proteins most likely originated from the $T$. ni cells (see sections on antibody production and characterization). Approximately $5 \mathrm{mg}$ purified rpIGFBP-3 could be isolated from 1 liter cell culture medium.

\section{Effect of rpIGFBP-3 on IGF-I-stimulated proliferation of PEMC cultures}

Figure 3 demonstrates that when IGF-I and rpIGFBP-3 were added simultaneously to PEMC cultures, rpIGFBP-3 suppressed IGF-I (1.33 nM)-stimulated proliferation in a concentration-dependent manner. When IGF-I and rpIGFBP-3 were added to the cultures at equimolar concentrations, rpIGFBP-3 completely suppressed the mitogenic activity of IGF-I (data not shown).

\section{Effect of rpIGFBP-3 on Long-R3-IGF-I-stimulated proliferation of PEMC cultures}

In order to assess the IGF-I-independent activity of rpIGFBP-3 in PEMC cultures, we examined its ability to inhibit Long-R3-IGF-I-stimulated proliferation. LongR3-IGF-I is an IGF-I analog that has very low affinity for the IGFBPs but retains its ability to bind to the type I IGF receptor and thereby stimulate proliferation. Consequently, suppression of Long-R3-IGF-I-stimulated proliferation by IGFBP-3 is believed to result from IGF-I-independent association of IGFBP-3 with cell surface receptors rather than binding and inactivation of IGF-I. Figure $4 \mathrm{a}$ shows that rpIGFBP-3 suppressed

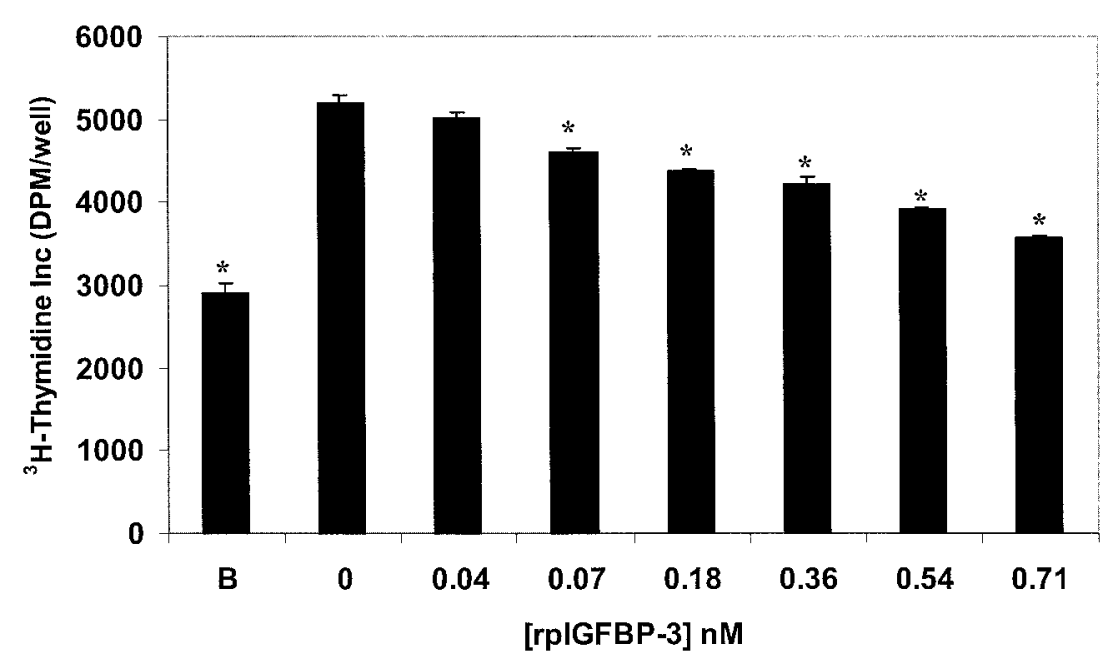

Figure 3 Effect of rpIGFBP-3 on IGF-I-stimulated proliferation of PEMCs. The bar labeled B shows ${ }^{3} \mathrm{H}$-thymidine incorporation in cultures treated for $24 \mathrm{~h}$ with basal medium containing no IGF-I. All other bars represent ${ }^{3} \mathrm{H}$-thymidine incorporation into cultures treated for $24 \mathrm{~h}$ with $10 \mathrm{ng} \mathrm{IGF-I/ml}(1.33 \mathrm{nM})$ and the indicated amount of rpIGFBP-3 prior to measuring ${ }^{3} \mathrm{H}$-thymidine incorporation as described in the Materials and Methods section. ${ }^{*}$ Values are different from 0 value $(P<0 \cdot 05)$ 


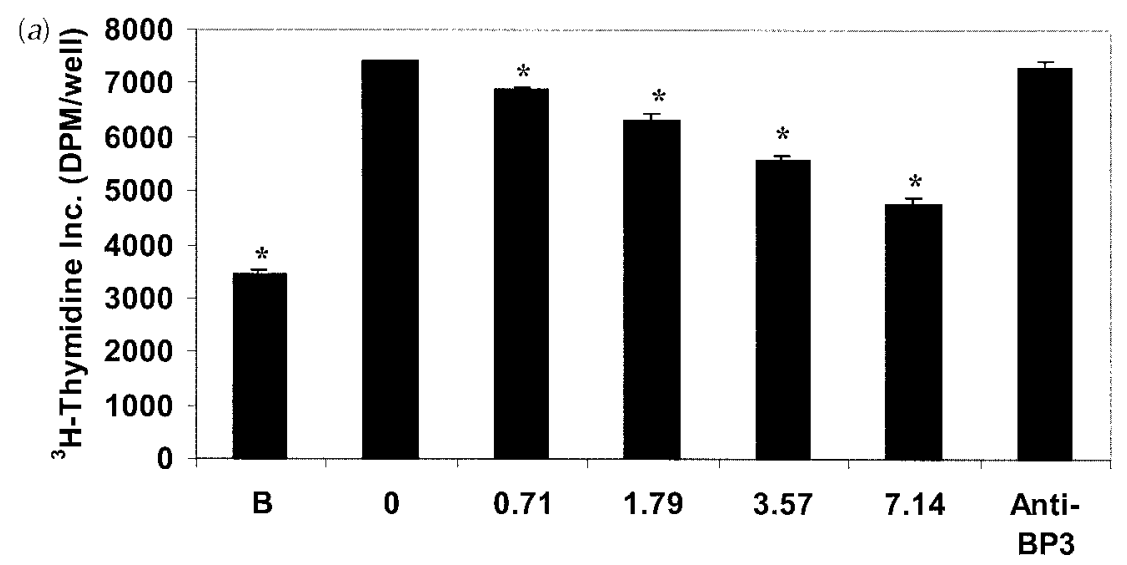

[rPIGFPB-3] nM

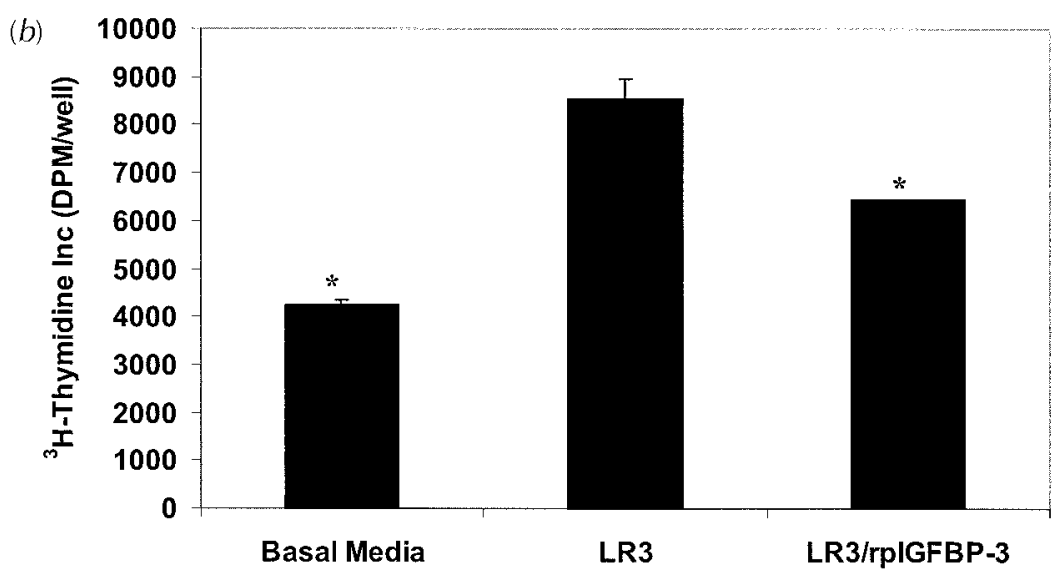

Figure 4 (a) Effect of rpIGFBP-3 on Long-R3-IGF-I-stimulated proliferation of PEMCs. The bar labeled $\mathrm{B}$ shows ${ }^{3} \mathrm{H}$-thymidine incorporation in cultures treated for $24 \mathrm{~h}$ with basal medium containing no Long-R3-IGF-I. The bar labeled Anti-BP3 shows ${ }^{3} \mathrm{H}$-thymidine incorporation in cultures treated for $24 \mathrm{~h}$ with basal medium containing $25 \mathrm{ng}$ Long-R3-IGF-I/ml $(3.33 \mathrm{nM})$, $7 \cdot 14 \mathrm{nM}$ rpIGFBP-3 and $80 \mathrm{mg}$ anti-rpIGFBP-3 $\mathrm{lgG} / \mathrm{ml}$ prior to measuring ${ }^{3} \mathrm{H}$-thymidine incorporation. All other bars represent ${ }^{3} \mathrm{H}$-thymidine incorporation into cultures treated for $24 \mathrm{~h}$ with $25 \mathrm{ng}$ Long-R3-IGF-I/ml $(3.33 \mathrm{nM})$ and the indicated amount of rplGFBP-3 prior to measuring ${ }^{3} \mathrm{H}$-thymidine incorporation. *Values are different from 0 value $(P<0 \cdot 05)$. (b) Effect of rpIGFBP-3 on PEMC proliferation in the presence of a large excess of Long-R3-IGF-I.

Basal Media: cultures were treated for $24 \mathrm{~h}$ with basal medium prior to measuring ${ }^{3} \mathrm{H}$-thymidine incorporation; LR3: cultures were treated for $24 \mathrm{~h}$ with basal medium containing 15.2 nM Long-R3-IGF-I prior to measuring ${ }^{3} \mathrm{H}$-thymidine incorporation; LR3/rpIGFBP-3: cultures were treated for $24 \mathrm{~h}$ with basal medium containing $15 \cdot 2 \mathrm{nM}$ Long-R3-IGF-I and $3.5 \mathrm{nM}$ rplGFBP-3 prior to measuring ${ }^{3} \mathrm{H}$-thymidine incorporation. *Values are different from LR3 $(P<0 \cdot 05)$.

Long-R3-IGF-I-stimulated proliferation in PEMC cultures in a concentration-dependent manner. Since LongR3-IGF-I still has some affinity for IGFBP-3 and the molar concentrations required to suppress Long-R3-IGFI-stimulated proliferation are high, it is possible that the suppression of proliferation observed in Fig. 4a results from binding and inactivation of Long-R3-IGF-I by rpIGFBP-3. To eliminate this possibility, we have examined the ability of rpIGFBP-3 to suppress proliferation of PEMC in the presence of a large molar excess of
rpIGFBP-3. Figure $4 \mathrm{~b}$ shows that $3.5 \mathrm{nM}$ rpIGFBP-3 suppressed proliferation in PEMC cultures containing 15.2 nM Long-R3-IGF-I. These data established that rpIGFBP-3 has IGF-I-independent effects on proliferation of cultured PEMC.

\section{Characterization of anti-IGFBP-3 antibody}

Purified rpIGFBP-3 was used to elicit antibody production in rabbits and anti-IGFBP-3 IgG was isolated as 


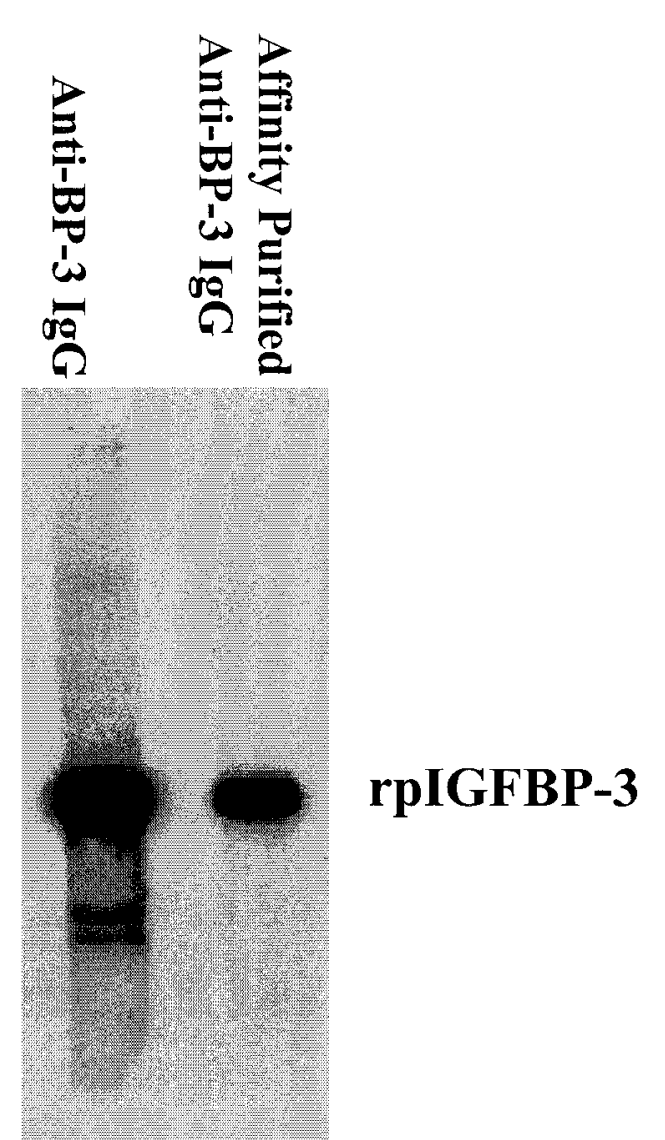

Figure 5 Western immunoblot showing the interaction of anti-rpIGFBP-3 against rpIGFBP-3. The lane labeled Anti-BP-3 was incubated with anti-rpIGFBP-3 IgG and then with phosphatase-labeled goat anti-rabbit $\operatorname{lgG}(\mathrm{H}+\mathrm{L})$ as described in the Materials and Methods. The lane labeled Affinity-Purified Anti-BP-3 IgG was incubated with anti-IGFBP-3 IgG that had been preabsorbed by passing through an affinity column containing bound soluble proteins from uninfected T. ni cells.

described in the Materials and Methods. Western immunoblots show that anti-IGFBP-3 IgG recognizes rpIGFBP-3 as well as proteins banding at approximately $14 \mathrm{kDa}$ (Fig. 5). In order to remove the antibodies recognizing these unidentified proteins, the antirpIGFBP-3 IgG was passed through an affinity column containing bound soluble protein from $T$. ni cells that had not been infected with the virus containing the rpIGFBP-3 construct. This column bound antibodies specific for insect proteins while allowing the antiIGFBP-3 IgG to pass through. Figure 5 (right-hand lane) shows that after passage through this column, the anti-rpIGFBP-3 IgG recognized only IGFBP-3.

Anti-IGFBP-3 recognized IGFBP-3 in PEMC conditioned medium (Fig. 6). Other bands recognized in the conditioned medium were recognized by the second antibody (Fig. 6) and were present in the fetuin and

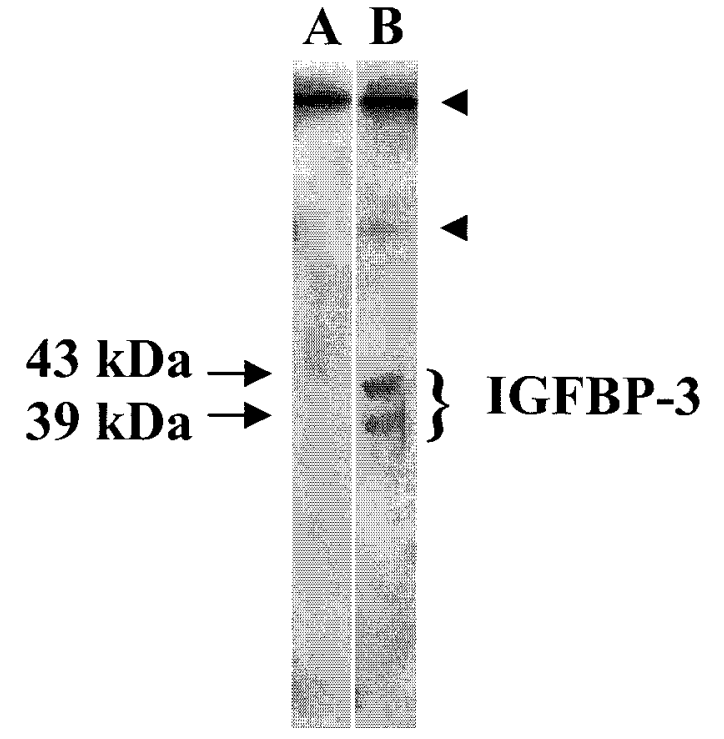

Figure 6 Western immunoblot showing the interaction of affinity-purified anti-rpIGFBP-3 with IGFBP-3 in cell culture medium conditioned for $24 \mathrm{~h}$ by PEMC cultures. Medium was concentrated approximately 10 -fold, mixed with the appropriate amount of tracking dye, electrophoresed on a $10 \%$ polyacrylamide SDS gel, and the proteins were electophoretically transferred to a nitrocellulose membrane. The membrane was probed with affinity-purified anti-rplGFBP-3 IgG followed by a phosphatase-labeled goat anti-rabbit $\operatorname{IgG}(\mathrm{H}+\mathrm{L})$ as described in the Materials and Methods. Lane A: PEMC culture medium incubated with second antibody only. Lane B: PEMC culture medium incubated with affinity-purified anti-rpIGFBP-3 followed by second antibody. The anti-rpIGFBP-3 recognizes only the 43 and $39 \mathrm{kDa}$ IGFBP-3 proteins (lane B). Other bands indicated by arrowheads are also present in the second antibody control (lane A) and are the result of interactions of the second antibody with proteins in the BSA and fetuin present in the serum-free medium used to grow the PEMCs (data not shown).

BSA-linoleic acid that are components of the serum-free medium in which the PEMCs were cultured (data not shown).

\section{Neutralization of IGF-I-dependent and IGF-I-independent IGFBP-3 suppression of PEMC proliferation by anti-rpIGFBP-3 IgG}

Anti-rpIGFBP-3 was able to suppress the ability of either rp-IGFBP-3 (Fig. 7) or commercially available recombinant human IGFBP-3 (data not shown) to inhibit IGF-I-dependent proliferation in PEMC cultures. Furthermore, these data showed that high concentrations of the antibody neither suppress nor stimulate proliferation of PEMC cultures, indicating that the anti-rpIGFBP-3 had no non-specific mitogenic effects on the PEMC cultures. Additionally, $80 \mu \mathrm{g}$ non-immune $\operatorname{IgG}$ had no effect on proliferation of PEMC cultures, further establishing that the effects of the anti-rpIGFBP-3 IgG were specific. Figure 4a shows that anti-rpIGFBP-3 IgG also inhibited 


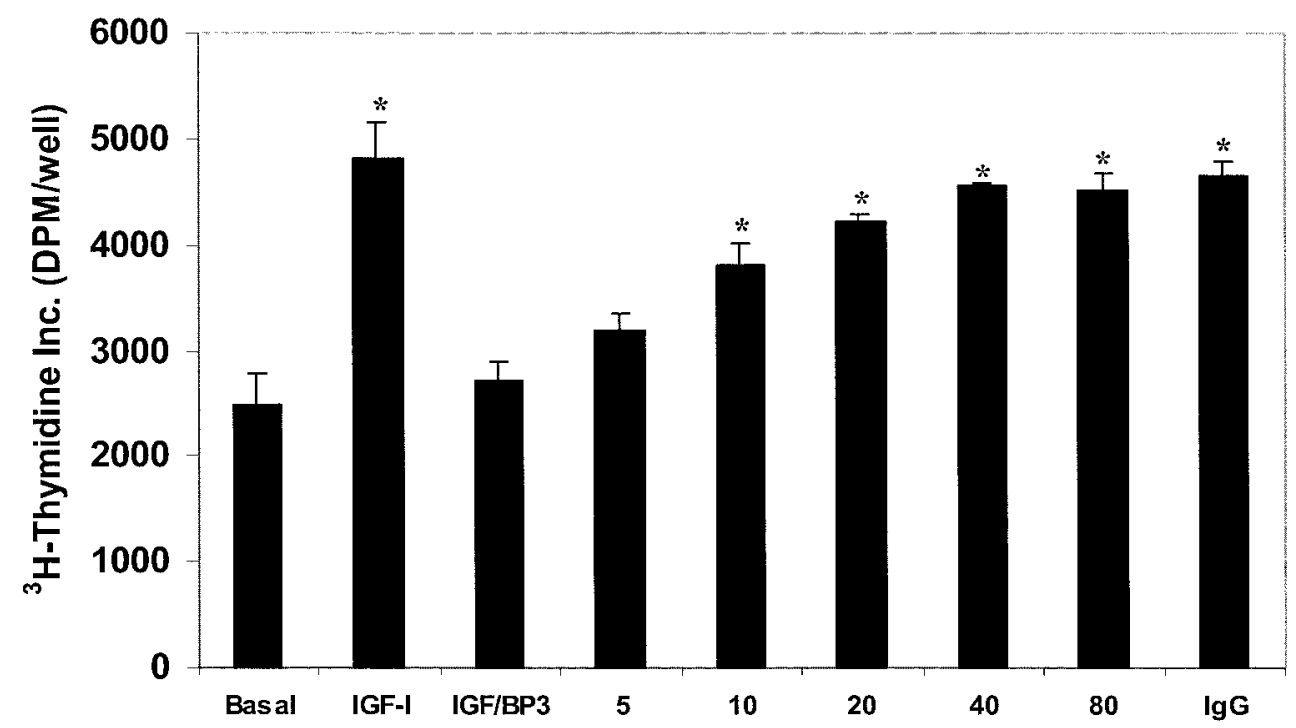

Figure 7 Effect of affinity-purified anti-IGFBP-3 IgG on the ability of rpIGFPB-3 to suppress IGF-I-stimulated proliferation of PEMC cultures. IGF-I: ${ }^{3} \mathrm{H}$-thymidine incorporation stimulated by treatment with $10 \mathrm{ng}$ $\mathrm{IGF}-\mathrm{I} / \mathrm{ml}(1 \cdot 33 \mathrm{nM})$; IGF/BP3: ${ }^{3} \mathrm{H}$-thymidine incorporation in the presence of $10 \mathrm{ng}$ IGF-I and $53 \mathrm{ng}$ rplGFBP-3/ml (1.33 nM); 5, 10, 20, 40 and 80: ${ }^{3} \mathrm{H}$-thymidine incorporation in the presence of $10 \mathrm{ng}$ IGF-I

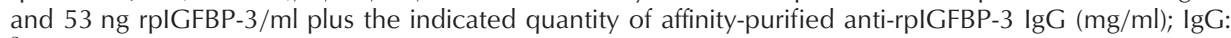
${ }^{3} \mathrm{H}$-thymidine incorporation in the presence of $10 \mathrm{ng}$ IGF-I and $53 \mathrm{ng} \mathrm{rpIGFBP}-3 / \mathrm{ml}$ plus $80 \mathrm{mg}$ non-immune $\mathrm{IgG} / \mathrm{ml}$. *Values are different for IGF/BP3 $(P<0 \cdot 05)$.

the ability of rpIGFBP-3 to suppress LR3-IGF-Istimulated proliferation of PEMCs. This result established that the interaction of rpIGFBP-3 with the antibody inhibits the IGF-I-independent actions of rpIGFBP-3 on PEMC.

\section{Discussion}

We have utilized a baculovirus expression system to produce $\mathrm{mg}$ quantities of $\mathrm{rpIGFBP}-3$, purified the rpIGFBP-3 to greater than $98 \%$ homogeneity using nickel and IGF-I affinity chromatography and demonstrated its ability to bind IGF-I. In addition, we have shown that IGFBP-3 suppresses proliferation of cultured myogenic cells via both IGF-I-dependent and IGF-I-independent mechanisms.

Finally, purified rpIGFBP-3 has been used to elicit production of an anti-rpIGFBP-3 antibody that is able to neutralize both IGF-dependent and IGF-independent actions of IGFBP-3.

It is well established that IGFBP-3 exists as a glycoprotein; however, glycosylation does not appear to be required for biological activity (Conover 1992, Firth \& Baxter 1999). Native porcine IGFBP-3 exists as two glycosylation variants migrating at apparent molecular weights of 39 and $43 \mathrm{kDa}$ on non-reducing SDS polyacrylamide gels (Yang et al. 1999). There are three potential glycosylation sites in the IGFBP-3 molecule and the $39 \mathrm{kDa}$ glycosylation variant is glycosylated at two of these sites while the $43 \mathrm{kDa}$ variant is glycosylated at all three sites (Firth \& Baxter 1999). Non-glycosylated IGFBP-3 migrates as a single band with a molecular weight of approximately $29 \mathrm{kDa}$ (Firth \& Baxter 1999). Since the rpIGFBP-3 in this study was produced and secreted from a eukaryotic cell system, the protein should be glycosylated. Comparison of the apparent molecular weights of rpIGFPB-3 (39 and $41 \mathrm{kDa}$ ), glycosylated native IGFBP-3 (39 and $43 \mathrm{kDa}$ ) and non-glycosylated IGFBP-3 (29 kDa) on non-reducing SDS gels strongly indicates that rpIGFBP-3 is glycosylated. It is likely that the production of a $41 \mathrm{kDa}$ glycoform in the baculovirus system reflects differences in glycosylation by insect cells versus mammalian cells.

Several studies have shown that if IGF-I and IGFBP-3 are mixed together in equimolar quantities prior to addition to cultured cells, IGFBP-3 binds IGF-I and effectively makes it unavailable to the type I IGF-I receptor (Jones \& Clemmons 1995). This results in total suppression of IGF-I-stimulated proliferation. This suppression is referred to as IGF dependent because it requires that IGFBP-3 binds IGF-I. Our data showed that rpIGFBP-3 suppresses IGF-I-stimulated proliferation of PEMC cultures in a concentration-dependent manner and that approximately $1 \mathrm{nM}$ rpIGFBP-3 completely abolishes the proliferation-stimulating activity of $1 \mathrm{nM}$ IGF-I. These data have established that rpIGFBP-3 has IGF-dependent activity in the PEMC system that is 
similar to that reported for native IGFBP-3 in other culture systems.

In order to assess the IGF-I-independent activity of rpIGFBP-3 in PEMC cultures, we examined its ability to inhibit Long-R3-IGF-I-stimulated proliferation in these cultures. Long-R3-IGF-I is an IGF-I analog that has very low affinity for the IGFBPs but retains its ability to bind to the type I IGF receptor and thereby stimulate proliferation (Kubler et al. 2002). Consequently, suppression of Long-R3-IGF-I-stimulated proliferation by IGFBP-3 is believed to result from IGF-I-independent association of IGFBP-3 with cell surface receptors rather than binding and inactivation of IGF-I. rpIGFBP-3 suppresses Long-R3-IGF-I-stimulated proliferation of PEMC cultures in a concentration-dependent manner, strongly suggesting that rpIGFBP-3 possesses IGF-independent activity in this culture system. These results also suggested that PEMCs possess receptors for IGFBP-3; however, the identity of these receptors is currently unknown.

The polyclonal antibody specific for rpIGFBP-3 is able to recognize native IGFBP-3 and Western ligand blotting shows that it is specific for only IGFBP-3. Additionally, the anti-rpIGFBP-3 antibody neutralizes the activity of both rpIGFBP-3 and commercially available recombinant human IGFBP-3. This antibody will be a useful reagent in studying the effects of endogenous IGFBP-3 on proliferation and differentiation of PEMC cultures.

In summary, we have shown that recombinantly produced porcine IGFBP-3 affects proliferation of cultured PEMCs via both IGF-I-dependent and IGF-Iindependent mechanisms. These data have established that IGFBP-3 produced by myogenic cells has the potential to affect proliferation of embryonic myogenic cells during critical periods of muscle development that may impact the ultimate muscle mass achievable postnatally.

\section{Acknowledgements}

This research has been funded in part by the University of Minnesota Agricultural Experiment Station, and in part by NRI Competitive Grants Program/USDA Grant No. 00-03271.

\section{References}

Baxter RC 2000 Insulin-like growth factor (IGF)-binding proteins: interactions with IGFs and intrinsic bioactivities. American Journal of Physiology. Endocrinology and Metabolism 278 E967-E976.

Baxter RC, Butt AJ, Schedlich LJ \& Martin JL 2000 Antiproliferative and pro-apoptotic activities of insulin-like growth factor-binding protein-3. Growth Hormone and IGF Research 10 (Suppl A) S10-S11.

Clemmons DR 1998 Role of insulin-like growth factor binding proteins in controlling IGF actions. Molecular and Cellular Endocrinology 140 19-24.
Conover CA 1992 Potentiation of insulin-like growth factor (IGF) action by IGF-binding protein-3: studies of underlying mechanism. Endocrinology 130 3191-3199.

Dahlfors G \& Arnqvist HJ 2000 Vascular endothelial growth factor and transforming growth factor-beta1 regulate the expression of insulin-like growth factor-binding protein-3, -4 , and -5 in large vessel endothelial cells. Endocrinology 141 2062-2067.

Drivdahl RH, Sprenger C, Trimm K \& Plymate SR 2001 Inhibition of growth and increased expression of insulin-like growth factor-binding protein-3 (IGFBP-3) and -6 in prostate cancer cells stably transfected with antisense IGFBP-4 complementary deoxyribonucleic acid. Endocrinology 142 1990-1998.

Fanayan S, Firth SM, Butt AJ \& Baxter RC 2000 Growth inhibition by insulin-like growth factor-binding protein-3 in T47D breast cancer cells requires transforming growth factor-beta (TGF-beta) and the type II TGF-beta receptor. Journal of Biological Chemistry 275 39146-39151.

Fanayan S, Firth SM \& Baxter RC 2002 Signaling through the Smad pathway by insulin-like growth factor-binding protein-3 in breast cancer cells. Relationship to transforming growth factor-beta 1 signaling. Journal of Biological Chemistry 277 7255-7261.

Firth SM \& Baxter RC 1999 Characterisation of recombinant glycosylation variants of insulin-like growth factor binding protein-3. Journal of Endocrinology 160 379-387.

Florini JR, Ewton DZ \& Coolican SA 1996 Growth hormone and the insulin-like growth factor system in myogenesis. Endocrine Reviews 17 481-517.

Granata R, Broglio F, Migliorino D, Cutrupi S, Baldanzi G, Sireno M, Fubini A, Grazian A, Ghigo E \& Pucci A 2000 Neonatal and adult human heart tissues from normal subjects and patients with ischemic, dilated or hypertrophic cardiomyopathy express insulin-like growth factor binding protein-3 (IGFBP-3). Journal of Endocrinological Investigation 23 724-726.

Hembree JR, Hathaway MR \& Dayton WR 1991 Isolation and culture of porcine myogenic cells and the effect of insulin, IGF-1 and sera on protein turnover in porcine myotube cultures. Journal of Animal Science 69 3241-3250.

Hembree JR, Pampusch MS, Yang F, Causey JL, Hathaway MR \& Dayton WR 1996 Cultured porcine myogenic cells produce insulin-like growth factor binding protein-3 (IGFBP-3) and transforming growth factor beta-1 stimulates IGFBP-3 production. Journal of Animal Science 74 1530-1540.

Hwa V, Oh Y \& Rosenfeld RG 1999 The insulin-like growth factor-binding protein (IGFBP) superfamily. Endocrine Reviews 20 761-787.

Jennische E \& Hall CM 2000 Expression and localisation of IGF-binding protein mRNAs in regenerating rat skeletal muscle. Acta Pathologica, Microbiologica et Immunologica Scandinavica 108 $747-755$.

Johnson BJ, White ME, Hathaway MR \& Dayton WR 1999 Decreased steady-state insulin-like growth factor binding protein-3 (IGFBP-3) mRNA level is associated with differentiation of cultured porcine myogenic cells. Journal of Cellular Physiology 179 237-243.

Jones JI \& Clemmons DR 1995 Insulin-like growth factors and their binding proteins: biological actions. Endocrine Reviews 16 3-34.

Kubler B, Draeger C, John H, Andag U, Scharf JG, Forssmann WG, Braulke T \& Standker L 2002 Isolation and characterization of circulating fragments of the insulin-like growth factor binding protein-3. FEBS Letters 518 124-128.

Kveiborg M, Flyvbjerg A, Eriksen EF \& Kassem M 2001 Transforming growth factor-beta1 stimulates the production of insulin-like growth factor-I and insulin-like growth factor-binding protein-3 in human bone marrow stromal osteoblast progenitors. Journal of Endocrinology 169 549-561.

Laemmli UK 1970 Cleavage of structural proteins during the assembly of the head of bacteriophage T4. Nature 227 680-685. 
Lawlor MA \& Rotwein P 2000 Coordinate control of muscle cell survival by distinct insulin-like growth factor activated signaling pathways. Journal of Cell Biology 151 1131-1140.

Leal SM, Huang SS \& Huang JS 1999 Interactions of high affinity insulin-like growth factor-binding proteins with the type $\mathrm{V}$ transforming growth factor-beta receptor in mink lung epithelial cells. Journal of Biological Chemistry 274 6711-6717.

Pampusch MS, Hembree JR, Hathaway MR \& Dayton WR 1990 Effect of transforming growth factor beta on proliferation of L6 and embryonic porcine myogenic cells. Journal of Cellular Physiology 143 $524-528$.

Tureckova J, Wilson EM, Cappalonga JL \& Rotwein P 2001 Insulin-like growth factor-mediated muscle differentiation. Collaboration between phosphatidylinositol 3-kinase-akt-signaling pathways and myogenin. Journal of Biological Chemistry 276 39264-39270.

Valentinis B, Bhala A, DeAngelis T, Baserga R \& Cohen P 1995 The human insulin-like growth factor (IGF) binding protein-3 inhibits the growth of fibroblasts with a targeted disruption of the IGF-I receptor gene. Molecular Endocrinology 9 361-367.

Wabitsch M, Heinze E, Debatin KM \& Blum WF 2000 IGF-I- and IGFBP-3-expression in cultured human preadipocytes and adipocytes. Hormone and Metabolic Research 32 555-559.

Yang F, Johnson BJ, White ME, Hathaway MR \& Dayton WR 1999 Effect of insulin-like growth factor (IGF)-I and Des (1-3) IGF-I on the level of IGF binding protein-3 and IGF binding protein -3 mRNA in cultured porcine embryonic muscle cells. Journal of Cellular Physiology 178 227-234.

Yi Z, Hathaway MR, Dayton WR \& White ME 2001 Effects of growth factors on insulin-like growth factor binding protein (IGFBP) secretion by primary porcine satellite cell cultures. Journal of Animal Science 79 2820-2826.

Received in final form 9 September 2002 Accepted 17 October 2002 